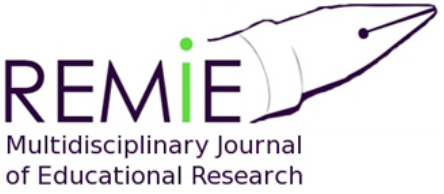

Multidisciplinary Journal

of Educational Research

\section{Hipatia Press}

www.hipatiapress.com

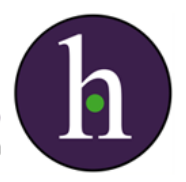

Instructions for authors, subscriptions and further details:

http://remie.hipatiapress.com

\title{
Inclusion of Sexual Diversity in Schools: Teachers' Conception
}

Elaine de Jesus Souza ${ }^{1}$, Leonor M. Cantera Espinosa²; Joilson Pereira da Silva ${ }^{3}$, Claudiene Santos ${ }^{3}$

1) Federal University of Rio Grande do Sul. Brasil

2) Autonomous University of Barcelona. Spain

3) Federal University of Sergipe. Brasil

Date of publication: June $15^{\text {th }}, 2016$

Edition period: June 2016-October 2016

To cite this article: Souza, E. J., Cantera Espinosa, L. M., Silva, J. P., \& Santos, C. (2016). Inclusion of Sexual Diversity in Schools: Teachers' Conception. REMIE - Multidisciplinary Journal of Educational Research, 6(2), 152-175. doi:10.17583/remie.2016.2004

To link this article: http://dx.doi.org/10.17583/remie.2016.2004

\section{PLEASE SCROLL DOWN FOR ARTICLE}

The terms and conditions of use are related to the Open Journal System and to Creative Commons Attribution License (CC-BY). 


\section{Inclusion of Sexual Diversity in Schools: Teachers' Conception}

Elaine de Jesus Souza

Federal University of Rio

Grande do Sul

Joilson Pereira da Silva

Federal University of Sergipe
Leonor M. Cantera Espinosa

Autonomous University of

Barcelona

Claudiene Santos

Federal University of Sergipe

\section{Abstract}

The school is permeated by a variety of individuals with different sexual identities and gender distinct from the heterosexual model, but sexual diversity is not included effectively in this social instance. Therefore, this qualitative study aimed to analyze the role of educators in the inclusion of sexual diversity in schools. For this, we used the method of thematic categorical content. The results showed that teachers were not trained in initial and continuing training to deal with sexual diversity, however, they highlight the need for a collective effort to host sexual diversity in schools and suggest teaching methodologies. So is cautioned that the undergraduate urgently need to include this subject in the curriculum, so that teachers are able to promote continuous actions along with the school community, contributing significantly to the inclusion of sexual diversity.

Keywords: inclusion, sexual diversity, educators 


\section{Inclusión de la Diversidad Sexual en las Escuelas: Concepción del Profesorado}

Elaine de Jesus Souza

Federal University of Rio

Grande do Sul

Joilson Pereira da Silva

Federal University of Sergipe
Leonor M. Cantera Espinosa

Autonomous University of

Barcelona

Claudiene Santos

Federal University of Sergipe

\section{Resumen}

La escuela está impregnada de una variedad de individuos con identidades sexuales y de género distintas al modelo heterosexual, sin embargo la diversidad sexual no está incluida de forma efectiva en esta instancia social. Este estudio cualitativo tuvo como objetivo analizar el papel de los educadores en la inclusión de la diversidad sexual en las escuelas. Para ello, se utilizó el método de contenido de categorías temáticas. Los resultados mostraron que los maestros no han sido capacitados en la formación inicial y continua para hacer frente a la diversidad sexual, sin embargo, ponen de relieve la necesidad de un esfuerzo colectivo para acoger la diversidad sexual en las escuelas y sugerir metodologías de enseñanza. Es por ello que se advierte de que los estudios de grado necesitan urgentemente incluir este tema en el currículum, de forma que el profesorado sea capaz de promover acciones continuas junto con la comunidad escolar, contribuyendo significativamente a la inclusión de la diversidad sexual.

Palabras clave: inclusión, diversidad sexual, profesorado 
I

$\mathrm{t}$ is known that schools are attended by a plurality of individuals with sexual orientation and gender identity which are different from sexual diversity is effectively included in this social scenario. These individuals are frequently marginalized or forgotten by members of the school institutions, including teachers, who in most cases had not been made aware (during the initial and continuing training) to accept and/or promote actions that allow the recognition/knowledge of sexual diversity.

Therefore, it is relevant to know the main difficulties that teachers encounter to address and include sexual diversity, as well as whether they seek to overcome the obstacles and perform the role assigned to them, since schools ideally count on the teachers in order to be pluralistic and democratic.

In this sense, the goal of the present study was to assess teachers' role in the inclusion of sexual diversity in schools. To this end, we sought to answer the following guiding questions: (a) How do teachers address (or not) issues relating to sexual diversity, such as sexuality and gender? (b) How should schools include sexual diversity?

\section{Sexual Diversity in Schools: Inclusion versus Exclusion}

The presence of diversity in today's society is clear and extremely challenging, because sociocultural, economic, political, sexual, or physical differences can significantly improve individuals' learning, sharing, and enrichment. Therefore, schools are precisely one of the spaces where diversity can be observed with the prevalence of gender plurality and sexual identities. However, restricted by walls and norms, such diversities are often forced to comply with arbitrary social patterns. This way, they are prevented from expressing their differences safely and democratically, resulting in exclusions and segregations.

It is noticeable that the school is one of the first places where individuals systematically meet human diversity (sexual, ethnic/racial, aesthetic, economic, sociocultural, and age groups, among others). Mutual contact can and should be enriching. However, there is a predominance of worldview conflicts and disputes, individual and group interests, 
expectations, and individual and collective projects that culminate in a series of practices that marginalize and exclude diversity, especially sexual diversity (Louro, 1997; Ramires, 2011).

In this context, sexual diversity involves multiplicity of expressions of sexuality and gender's experiences that make up the human being, including sexual identities (heterosexual, homosexual and bisexual) and gender identities, among which stand out transvestites and transsexuals. It notes that heteronormativity adopts heterosexuality as the norm socially recognized. This compulsory use, usually delete the heterosexuality as a part of sexual diversity term; since what is considered normal would not be named (Louro, 1997; Nardi, 2012).

Society is organized through the distinction of behaviors relating to sociocultural norms that create standards of desirable and undesirable behaviors. In many cases, schools adopt and (re)produce such values. As a result, they intensify the exclusion of individuals who exhibit behaviors that do not comply with the current sociocultural model, i.e., the heteronormative logic (Louro, 2001). As a result, there is increased young lesbian, gay, bisexual, and transgender (LGBT) individuals' exclusion. Since these individuals do not identify themselves with those codes, they end up dropping out of school.

There is a need of discussions and debates on sexual diversity in the schools in order to eradicate that type of exclusion. These measures will allow teachers and the whole school community to be aware and recognize, reflect, and find a direction with respect to important ethical values, such as respect and full citizenship. It is worth stressing the importance of valuing and accepting the individuals in the school space, regardless of their sexual orientation and gender identity. Discrimination and segregation threatens the inclusive and democratic role of schools. In addition, these behaviors promote intolerance of diversity causing homophobic practices that range from verbal assaults to serious bodily injuries (Kamel \& Pimenta, 2008).

Teachers' engagement can significantly contribute to the inclusion of sexual diversity in schools. In fact, the results will be beneficial for both students' learning and well-being and the teachers. However, enough patience, studies, debates, and reflections on the current Brazilian educational and political situation are necessary to eradicate teachers' point 
of view that inclusion is a source of endless problems. This way, they will be able to perceive and understand the richness of diversity in the classroom, in this case sexual diversity. Although most individuals agree with the importance of inclusion and learning, achieving this purpose in practice requires enormous effort and willingness on the part of those involved in the educational process, especially teachers. This way, they will develop and perform actions to overcome prejudices by recognizing and accepting diversity (Seffner, 2009).

Thus, the crucial matter that should be clear and recognized in the school environment is that society is plural. Sexual diversity is an issue that should be discussed by teachers in the classroom, because it is present in the social reality. Its presence is marked by hegemonic heteronormative morality that causes serious social damage and violation of human and sexual rights to many individuals (Lionço \& Dinis, 2009).

According to Foucault (1999), educational institutions (as well as others including the family) with their multiplicity of individuals, hierarchies, special organizations, and monitoring system constitute a space in which the game of powers and pleasures are established and distributed. However, the school also represents a high sexual saturation region with privileged environments and rites, such as the classroom. In that sense, the discourse on sexual diversity produces, reiterates, and carries power. However, at the same time, this discourse also weakens, displays and discourages sexual diversity. On the other hand, while silence and secrecy around sexuality give shelter to power and establish its interdictions, they can also be used to hide it and cause obscure tolerances with respect to dominated individuals or sexual minorities.

Furlani (2009) points out that a political reflection on sexual diversity does not only propose that these individuals with sexual orientations and gender identities should be tolerated; above all, it promotes social inclusion and living with them without prejudices. Therefore, in addition to respecting individuals with attitudes and behaviors that do not comply with heteronormative social standards, they should be recognized as citizens with equal human rights. At the same time, power relations that insist on marginalizing such differences should be questioned. 
According to Seffner (2009), it is essential that the school structureespecially with respect to its members and rule - is modified to accept and effectively include students who are lesbians, gays, transvestites, or have another sexual orientation and gender identity. The first step should be the abolition of jokes, sexist manifestations, and subtle homophobic attitudes on the part of teachers toward students who are different with respect to heterosexual patterns. It is impossible to teach in an environment in which the lack of respect for diversity prevails, in which verbal and/or even physical aggression is a weapon to expel young individuals who do not fit the heteronormative model.

From another perspective that values diversity, school can be regarded as a fundamental means of access to equal rights (Nardi, 2010). In current society, which is considered democratic, the perpetration of human rights violations, prejudices, and discrimination against individuals who differ from social norms prevail. This can be observed in schools on a continuous and permanent basis, especially with respect to sexual diversity, which should be urgently accepted. To that end, actions aimed at promoting the destabilization and eradication of homophobic practices are crucial.

In this context, it is worth pointing out that there will be no quality education in public schools (and also in private schools) without a real concern with inclusion, which should involve attention and genuine promotion of sexual diversity recognition and acceptance. Without this attitude, children, young individuals and teachers will not be properly prepared for another possible and legitimate world (Seffner, 2009).

For Santos and Bruns (2000), schools should open a space for continuous reflection, so that teachers can be updated and receive information. As a result, they will be prepared to address sexuality more widely, since in most cases they do not acquire the necessary knowledge about this relevant transversal issue during their academic training.

In this way, schools should promote actions that create an environment for acceptance and inclusion of differences, in which sexual issues can be discussed and sexual diversity finds a space to be recognized. Furthermore, it must be considered that schools are secular and, this way, the rules imposed by religions regarding human sexuality should remain outside the 
school environment. School rules should be democratic, pluralistic and not characterized by moral standards (Seffner, 2009).

To Seffner (2013), the school could represent a space of experimentation and (re) construction of masculinity and femininity, as well as expression of sexual and gender identities. However, the traditional role of the school would be directed to suppress the trials about sexuality and gender, contributing to the maintenance of normalization around male and female, which reinforces homophobia and other forms of prejudice and discrimination. In this sense, it seems relevant to question how gender relations and power are established in the classroom as well as invest in anti-homophobia programs on they involved schools, family and representatives of the lesbian movement, Gay, bisexual and Transgender / LGBT.

The diversity of individuals who attend schools contributes to learning, because others' experiences may enable the personal growth and intellectual maturity of young individuals. This way, sexual diversity in the school environment can be a valuable tool when used to highlight the multiple dimensions and experiences of sexuality and gender. In this context, it is worth mentioning the importance of analyzing teachers' role relating to the inclusion of sexual diversity in schools as a means of encouraging this approach and providing teaching suggestions for achieving such a purpose.

\section{Method}

This qualitative study was conducted in a public school of Simão Dias, a municipality in the State of Sergipe, Brazil. The choice of this location was due to the scarcity of studies addressing the inclusion of sexual diversity in the state. We interviewed seven elementary school teachers of Portuguese, mathematics, sciences, geography, history, English, and physical education. To ensure teacher's anonymity, the names used in the present study are fictitious.

We used a semistructured interview based on the bibliography studied (Dinis, 2012; Madureira, 2007; Silva, 2010; Tosso, 2012) as a technique for collecting relevant information. The project was approved by the Ethics 
Committee. Subsequently, we requested the authorization of the schools for the participation of the teachers. The teachers signed an informed consent form before the interviews were conducted.

As a proposal to assess the information collected, we used thematic content analysis. This procedure consists in dismembering the texts into units of meaning-i.e., determining the main opinions, beliefs, and concepts - found in the answers to the open questions of the interview. Subsequently, these units were grouped into categories of analysis (Bardin, 2011).

\section{Results and Discussion}

The results obtained were grouped into the following categories: (a) "Sexual Diversity and teachers' role", which is mainly related to the way in which teachers deal with sexual diversity in the school environment; and (b) "How should schools include sexual diversity?", which encompasses some teachers' suggestions for strategies to include sexual diversity in the school environment.

\section{Sexual Diversity and Teachers' role: How to Include without Training?}

The teachers' reports revealed that during initial and continuing training they had not been prepared to deal with sexual diversity in schools. However, most of them recognized the relevance of this issue and some of them had eventually tried to address it. Therefore, it is obvious that, without adequate and consistent knowledge of that issue, it becomes difficult to promote a meaningful approach that contributes to the effective inclusion of sexual diversity in schools.

This way, when the teachers were asked whether they used to conduct discussions on sexual diversity, sexuality, and gender in the classroom, most of them confessed that they did not address such issues directly (with prior planning), but only when questions and doubts arose.

No. I haven't addressed these issues so far. (Lúcio)

So far, not at the moment, so it is sometimes through talks. [...]

(Talita) 
[...] When it arises... some question in the classroom, usually when they listen to journalistic reports, something like that, that questions. We make a little pause and address that issue. Now, I never designed anything like a project focused on this issue. (Roberta)

At the moment, I don't remember a specific discussion on this issue. But, whenever there is an opportunity [...] that a student bullies others, I always address the situation of respecting the others. (Samuel)

[...] not all the time, but if the issue [...] arises, we ... not in depth, because maybe we don't have that knowledge, but when the issue arises and because it's an issue that if we permit, they like it ... right? (Claudia)

These reports reveal that one of the main reasons that prevent a planned approach to sexual diversity, sexuality, and gender is the lack of knowledge on the part of the teachers. This fact occurs because these issues are not addressed in the initial or continuing teacher training. In addition to this reason, the following reports include other factors that hamper the inclusion of these issues in schools, i.e., content-based curriculums unlinked from social reality, absence of such issues in textbooks, and obstacles posed by school directors and students' parents.

And when it comes to mathematics class, then we get really tied to calculation, the exact sciences. [...] (Roberta)

[...] Perhaps due to the daily routine, the contents and... yes... perhaps because of that, right? [...] It was never addressed in my training [...] So, maybe this is why I don't address it much. (Samuel)

[...] sometimes it's not teachers' fault [...] the coordination of the school prevents that, sometimes the parents ask the coordination to avoid addressing these issues. (Talita)

[...] So, from the moment that you don't see it in a textbook, right? [...] with a broader approach in this regard [...] you're omitting, leaving people, the students without proper knowledge of what happens in society and I think that's why there is greater prejudice. [...] (Lúcio)

The teachers stressed that it would be easier to address these issues if the training had provided at least the necessary basis. Even those teachers who exhibited inconsistent representations about sexual diversity, implied that knowledge could enable addressing this issue and the eradication of the prejudices in the classroom. 
Yes, maybe if there had been during my teacher training [...] more dialogue in the classroom, much more, right? Talks, even many more studies in the area, maybe we could come to the classroom with that intention of putting into practice what we had heard there. (Roberta) [...] I think we still have much to learn [...] not that we still have those taboos [...] but, we need to participate more in courses, we need to be there improving more, you know... so we can talk more. [...] (Claudia)

Therefore, for a significant approach to sexuality and gender that favors recognizing sexual diversity in schools, it is essential that the teachers undergo professional training addressing technical, scientific, methodological, and experiential content. The goal of this training would be reflecting, analyzing, and guiding in accordance with the peculiarities of each age group, paying attention to the bio-psycho-socio-cultural complexity of its construction (Louro, 1997).

Although the teachers did not address such issues directly, some of them highlighted the need to speak clearly and coherently about these issues at school. As the main members of this social instance, they also have to seek knowledge in order to eradicate prejudices relating to sexuality and sexual diversity.

However, determining which teacher is qualified to work with the issues relating to sexual diversity at school is not the best way to include this issue. Teachers should not be forced to address sexual diversity in their classrooms if they do not feel comfortable and confident to do it in a safe and pluralist manner (Seffner, 2009).

Several factors prevent teachers from addressing sexual diversity. Some of these obstacles are: religious beliefs and/or conservative moral values; lack of addressing this issue in initial and continuing training; lack of specific materials to support the discussion of sexual differences; and lack of support and even prohibition by school directors. Moreover, the difficulty in talking about sexual diversity also involves the beliefs and social patterns that prevent teachers from knowing their own sexuality and the multiple possibilities for experiencing and expressing it. Therefore, it is imperative to question and problematize every form of standardizing. This way, it will be possible to understand sexuality as a construction in constant negotiation with each other and society, comprising plurality of individuals, i.e., several identities in detriment of heteronormative assumptions (Dinis, 
2012; Louro, 1997; Seffner, 2009). To that end, it is worth noting that the effective inclusion of topics relating to sexual diversity in undergraduate and graduate programs is a significant measure.

Although the teachers affirmed that had not addressed sexual diversity, sexuality, and gender in a direct manner at school, some of them stated that, when there was an opportunity, they encouraged superficial discussions about those issues in the classroom, mostly about sexuality.

[...] in the classroom, I have already taught Science in the seventh grade. So, it is the human body, isn't it? And... it draws to this issue of sexually transmitted diseases, prevention. [...] (Roberta)

[...] not only at that moment, but current reality, yes... prejudice, sexual diversity. I always take a time in my lessons to talk with them, let's say informally. I try... to draw things from them... my things too, right? [...] (Camila)

Not directly [...] For example, now in the seventh grade I worked the reproductive system, previously I had worked the issue of sexuality, about prevention, then, at that point, I bring complementary texts that I can directly or indirectly refer to what I would like to raise. (Antônio)

Usually here at school we have "adolescent's week" and [...] there's a day in which the lectures address the issue of sexuality, [...] during that week they just talk about that ... and it is there when it arises, there are doubts, questions, and then 10, 15 minutes you can know that the lesson will be about that, but it arises naturally. (Claudia)

In these statements, it is possible to observe that the superficial and informal approach to sexuality and sexual diversity can contribute to the reiteration of prejudices. Since the teachers do not have the knowledge required to discuss these issues in a clear, consistent, and continuous manner, they end up using a biologized conceptualization based on the essentialist, hygienic, and preventive dimension of sexuality. This random and unidirectional approach with no social and cultural contextualization can accentuate the impasse in the idea of social construction of sexuality and sexual diversity. As a result, it will contribute to the dissemination of sexual and gender stereotypes (Louro, 1997).

Furthermore, in the course of the interviews, the following question arose: What is the teachers' role in the inclusion of sexual diversity at school and confrontation of homophobia? Most participants believed that 
teachers should propose and adopt strategies to address sexuality and sexual diversity (even though they did not do that). This should be done with the purpose of clarifying students' doubts and curiosities, thus contributing to the effective inclusion of diversity and the eradication of prejudices. This perspective can be observed in the following statements:

Very important, right? as we are who help them become critical citizens, [...]I believe that it should be worked [...] along with the coordination, direction, dialoguing with the students, if possible including it in an interdisciplinary way with the other school subjects. [...] (Talita)

[...] Then, teachers should search for the best strategy together with the school, together with the other teachers to address the issue. (Samuel)

Within the limits of their autonomy in the classroom, the teachers should address those issues. Because it is a recurring issue, in our students' daily life. [...] So, they bring a lot to the classroom and, because of this, debates and even clarifications are encouraged by the teachers. (Roberta)

They have to intervene in the dialogues for improvement. [...] and in the question of these biased people, see [...] this matter of mutual respect. [...] If the teacher is a committed person, responsible and all that stuff, the students will identify themselves with the experience, the discourse, the persistence, it's not something that will occur immediately, but if you persist it is possible. (Antônio)

In addition to the active collaboration for the formation of aware and critical citizens, significant engagement of teachers in this process of sexual diversity inclusion and confrontation of homophobia requires the adoption of a pluralistic and democratic stance. Teachers should question and problematize their own conceptions (including the beliefs and prejudices that are part of their representations) and practices. At the same time, they should seek for educational experiences and dynamic teaching methodologies that promote students' development and theirs. This way, the value of diversity (sexual) will be understood and recognized (MEC, 1999; Pereira, 2010). 


\section{How should Schools Include Sexual Diversity?}

It is something unquestionable that schools should effectively include sexual diversity. However, inquiries are recurrent, as for example: How can inclusion be put into practice? Which are the educational and methodological strategies that teachers should adopt so that the approach to this issue contributes to inclusion? Although it is difficult to fully answer such questions, a promising path for beginning the inclusion of sexual diversity at school is precisely collective commitment of all school community members. This way, everyone, and not only teachers, will seek knowledge to promote equity and acceptance of individuals' diversity.

In this context, the teachers were asked to give their opinions about how the school should deal with issues relating to sexual diversity (heterosexuality, homosexuality, bisexuality, transvestism, and transsexualism, or even gender identities which are not in accordance with the heteronormative model). The answers showed that despite all the controversies and difficulties (not addressing the issue in teacher training, religious influence, content-based curriculums, among others) that prevent effective acceptance of sexual diversity at school, the teachers argued that the institutions should work sexuality and sexual diversity in order to eradicate prejudices and taboos. This is reported in the following statements:

The role of the school is to guide. [...] it is to be aware that in today's world... they are present everywhere... yes... sexual diversity and acceptance. Yes, to accept, guide, because insults, exclusion is not worth it, it is not worth it for who does it and who receives it. [...] (Camila)

[...] the school should... include, right? these issues in full in students' daily life. To perform some seminars, right? [...] some events at school that address, bring people of this segment just to explain: "People, look, sexuality is that $[\ldots] "$ that is, to clarify $[\ldots]$ and not leave the students with this prejudice of seeing a different person, [...] and have some other hostile attitude. [...] (Lúcio)

First, I think that there should be that opening in the classroom, perhaps, right? if the school had... if its own curriculum were already directed to that [...] But, it's a good start when you have this opening in the lectures, but $[. .$.$] there is still a need to have that awareness,$ 
primarily by the school direction, to promote this opening, I think it is a whole group. (Claudia)

Look at how education should be based on the principle of democracy and freedom of expression, the formation of the school in this regard [...] awareness, maturity, arguing against some prejudiced idea and indifferent attitudes that occur out there. (Antônio)

Nevertheless, although the teachers agreed that the school should address and include sexual diversity, some of them expressed some concern as to how this issue should be worked, since it is something controversial and considered taboo:

So, I guess that... the school... maybe it shouldn't approach this issue specifically, right? I think it should be... diversity in all ways, right? not just sexual. So ... older adults, women, right? black, slim, fat individuals. [...] So, [...] we have to be very careful $[\ldots]$ because otherwise some student might be embarrassed. (Samuel)

The most natural way possible, I know it's hard, because it really shocks people, it shocks the family when someone admits that sexuality. [...] but, so far, during this time at the school, I've never seen these issues being worked naturally nor seminars being held, I don't see these things, not so far. (Talita)

According to Blaine (2007), diversity (either sexual, ethnic, religious, social, among others) involves many dimensions of difference that are associated with inequalities and disadvantages. For this reason, diversity is also a concern of individuals who value and fight for social justice. The latter can only exist when all groups of individuals (LGBT, blacks, Jews, among others) enjoy the same rights and opportunities, and when the results of their lives are not unfairly constrained by prejudices and discrimination. Therefore, besides homophobia (or prejudice against homosexuals and all individuals with sexual orientation and gender identities that are not in compliance with the heteronormative model), several types of prejudices relating to various groups socially stereotyped and devalued are pointed out. Some of them are: prejudice against women (sexism); prejudice against older adults (ageism); racial prejudice (racism); prejudice against fat individuals; and prejudice against individuals with special needs. These prejudices are recurrent in the Brazilian society, including the school environment, where democratic plurality and 
recognition of all forms of diversity should prevail (Abramovay, Castro \& Silva, 2004; Carrara \& Lacerda, 2011; Lima \& Vala, 2004).

There is no doubt that schools have a fundamental role in the recognition of sexual diversity, as well as in combating intolerance and prejudices that characterize homophobia. To that end, schools should disseminate the concept that equality between gays, lesbians, bisexuals, transvestites, and transsexuals is everyone's responsibility, especially of those engaged in the educational process. This way, sexual orientation and gender identities should be presented in school subjects, educational instruments, and teacher training courses as legitimate manifestations that do not differ from heterosexuality (Borrilo, 2009). In addition, it is worth noting that

The creation of conditions to deal properly with the issues relating to sexual diversity and sexual rights in schools depends, to a large extent, on public education policies and social mobilization activities aimed at destabilizing the production of hierarchies, oppressions, and divisions relating to heteronormative patterns - which have historically modulated and modulate gender relations - and the dynamics of differences and inequalities (re)production (Junqueira, 2009b, p. 163).

It is noticeable that the obstacles to the approach and effective inclusion of sexual diversity at school and confrontation of homophobia can be overcome if the work is developed continuously in a collective manner. Partnerships should be established between all members of the institution and students' families. Such perspective can be observed in the following statements:

So, I think so ... that it's general. It's the school; it's the community, isn't it? The community coming to the school. It's the school direction, the teachers, the students. All of them have to mobilize themselves, right? It's the mobilization of the school and the community. (Camila) [...] Nobody does anything alone, an integration between school and society. School-society and those organizations that advocate sexual diversity. Then, [...] the teacher would be a mediator in that respect. [...] between those organizations that advocate diversity and the students, right? (Lúcio)

[...] The school community itself, I think it should have that focus, [...] this issue of dealing, sexuality [...] as an issue of utmost importance, [...] I think that if there were greater concern on the part of the school 
itself as in other areas that we work, in a much more focused way, I think there will be a positive effect. (Claudia)

The school and the families. Both have been trained. And the school itself, [...] it is concerned about educating just for life, about living with the others, the relationship with each other, in addition to contributing to the families and the social environment. [...] I think that the work should be collective. [...] when working as a team, the school direction, teachers, all of them interact, they think in terms of changes [...] (Antônio)

In fact, to achieve this difficult task of including sexual diversity and combating homophobia, it is essential to involve all education professionals, members of the school community, authorities, and the society in general besides teachers. In this way, it is possible to create partnerships with other institutions and social movements (such as the LGBT movement) in order to perform actions together. Such actions would include projects, workshops, and discussion groups on sexual diversity and homophobia. Educating in diversity (which should also be for and by) is a project that should be built collectively by engaging the school and all human diversity that composes the social dynamics (Junqueira, 2009a, 2009b; Seffner, 2009).

By means of the guiding questions of the interview, namely: (a) How do teachers address issues relating to sexual diversity, sexuality, and gender in the classroom? and (b) How should schools include sexual diversity?), another question raised: What measures or strategies can schools adopt through the teachers to effectively include sexual diversity and combat homophobia? As a result, the following statements make suggestions for educational and methodological strategies:

Yes... lectures, yes... cultural workshops discussing the everyday world. Showing that $[. .$.$] these situations occur daily, that they are$ included in society. (Camila)

[...] I think about videos, journalistic reports showing attacks experienced by homosexuals. [...] I find that it is very interesting to work with videos, songs, cartoons, and journalistic reports. So, I think it is a very interesting strategy... Internet research is also interesting, isn't it? (Samuel) 
Projects, texts. I still think that complementary texts are a solution... because in addition to promoting reflection, they work the issue of values, we work the content itself. [...] Debates [...] (Antônio)

So, the school should work with thematic seminars, videos, inviting a psychologist, for example, or social workers... to work with this issue in a lecture, a workshop [...] (Talita)

[...] we have the Adolescent's Week here at the school, which [...] lectures are delivered to attract the attention of young people. It's just when debates arise regarding these issues. Sexuality, drugs, family, religion. [...] (Roberta)

[...] I think it should start from planning together [...] If we give that emphasis also in this issue, more deeply [...] not just every now and then with a lecture, but in a more constant way [...] (Claudia)

The full inclusion of sexual diversity and confrontation of homophobia at school requires that the teachers invest in planning and systematic educational modalities, and not only in lectures, posters, murals, and special weeks. It is necessary that the teachers are able or seek training and materials to discuss the issue. They should do that in a meaningful, clear, and comprehensive way when teaching their school subjects and/or create interdisciplinary projects addressing sexual diversity, sexuality, gender, and other related issues. In addition, they should carry out activities and continuous approaches that enable the eradication of prejudices (Maistro, 2009; Seffner, 2009). In this context:

The issue of sexual diversity can be approached in some specific school subjects, or in the form of projects that gather various school subjects; it can be present in the school services, such as the library, supervision, educational advising, or it can occur in parallel with the activities of the social movement, as "Gay Pride Parades". Finally, we have to be creative to make the issue emerge in many ways and especially linked to the students' interests and the situations experienced by them. (Seffner, 2009, p. 137)

This way, it can be inferred that the main strategies for the inclusion of the plurality of individuals with sexual orientations and gender identities in schools require diverse approaches. In addition to expository lessons, these approaches should include several educational modalities through dialogue, such as group dynamics, educational games, role plays, videos, music, posters, texts, case studies, debates, and drawings. Above all, the teachers 
should create spaces for the students in order to clarify their main questions and reflect on the importance of diversity at school and the serious consequences of prejudices disseminated by homophobic practices.

Finally, it is worth mentioning that most teachers-even with all the uncertainties, inconsistencies, and contradictions about sexual diversitybelieved that despite being a controversial issue, the schools should perform their transforming role assisting in the eradication of taboos and prejudices related to "the different". This way, they will enable the confrontation of homophobia and the inclusion of individuals' diversity in this social space. This concept can be understood in the following statements:

It's a delicate issue, isn't it? But it has to be addressed. [...] Yes... still considered a taboo, but that's why it has to be discussed, to no longer be a taboo, isn't it? [...] And the school is one of the best places to work it. (Samuel)

The schools would have to think about coexistence, not only in the school environment, but also as a whole, because teaching will interfere here, yes... for a life outside the school. And this can greatly contribute, besides being something that affects the life of every human being, above all we must think that all are human beings and we should be respectful. (Antônio)

It should be noted that the schools need to urgently stop being a disciplinary and normative space that produces inequalities. They should promote the eradication of logical and traditional commitments that maintain hierarchies in favor of individuals that fit into a certain modelsuch as the heteronormative model - to the detriment of others who exhibit their pluralities. To that end, it is necessary to problematize the production and activation of these mechanisms through initial and/or continuing teacher training on sexuality, creating guidelines for education systems, in addition to administrative and legislative measures. The schools should discuss and promote: curricular reforms; development and distribution of educational and supplementary material; intra- and inter-institutional partnerships; research and scientific dissemination; modalities of education funding; international cooperation; and social mobilization mechanisms, which together can promote the confrontation of homophobia and the effective inclusion of sexual diversity in schools (Junqueira, 2009b). 
The pedagogical practices and contemporary studies about the school as institution have shown that in our society the binary and exclusionary logic operates from a legitimate identity as the norm; read as male, white, heterosexual, middle and Christian class, so the subjects who do not fall into such identity markers are marginalized, invisible and / or discriminated against (Louro, 2005; Meyer, 2013). In contrast, it seems more productive for the educators and the whole school institution discuss and to make problematic how those normalizations are (re) produced and which discourse, crossed by power relations, are involved in, toward the recognition that diversity (whether sexual, gender, ethnic / racial, socioeconomic, religious) assumes a more complex logic that the binary oppositions. Therefore, this multiplicity of subjects, experiences and expressions of sexuality and gender suggest the abandonment of dichotomies and hierarchies (Louro, 2013; Meyer, 2013) to allow for the deconstruction of homophobia, as well as the recognition and inclusion of sexual diversity at school and at all social levels.

\section{Final Considerations}

The urgent need to seek knowledge for developing educational and methodological strategies that allow the eradication of prejudices and the effective inclusion of sexual diversity in the schools stands out among the different roles assigned to teachers. However, it is worth mentioning that this role cannot only be performed by one social group, but by all members of the school community (and society in general).

The need and importance of further research and intervention actions addressing sexuality, gender, and sexual diversity stand out, particularly in the State of Sergipe, where the scarcity of studies, the lack of knowledge, and the omission of those issues prevail.

To this end, we stress that initial and continuing teacher training should urgently include the issues of sexuality and sexual diversity in their curricula, so that teachers can be made aware in order to eradicate their own prejudices and problematize sex and gender standards together with the other school members. They should promote educational strategies in a collective manner, such as the reformulation of the school curriculum for 
inclusion of topics relating to sexual diversity and the development of educational and methodical actions that allow continuous and significant approaches to sexual issues. This way, teachers will allow questioning the heteronormative model, aiming at eradicating homophobia at school and ensuring equity among all the individuals starting by the recognition and the effective inclusion of sexual diversity.

These reflections run through the constant questioning: How to include sexual diversity in school and deconstruct prejudices without significant training? Without intending to point ready and certainties answers, it seems more productive to develop continuous and systematic actions that provoke the questioning of discourse, knowledge and practices permeated by unequal power relations that establish norms and hierarchies in different social agencies like school. In this way, perhaps the educators with the whole school community are encouraged them to seek (in) formations contributing to criticism and new possibilities for analysis, (re) think the themes about sexuality, gender and sexual diversity, aiming recognize that sexual and gender identities are fluid and dynamic, not static and dichotomous as is recommended by the heteronormative model socioculturally imposed.

\section{References}

Abramovay, M., Castro, G. M., \& Silva, L. B. (2004). Juventudes e sexualidade. Brasília: UNESCO Brasil.

Bardin, L. (2011). Análise de conteúdo. Lisboa: Edições 70.

Blaine, B. E. (2007). Understanding the Psychology of Diversity. Los Angeles: SAGE Publicacions.

Borrillo, D. (2009). A homofobia. In T. Lionço \& D. Diniz (Orgs.), Homofobia \& Educação: Um desafio ao silêncio (pp.15-46). Brasília: LetrasLivres: EdUnB.

MEC, Brasil. (1999). Secretaria de Educação Fundamental. Parâmetros curriculares nacionais: Orientação sexual. Brasília: MEC/SEF.

Carrara, S., \& Lacerda, P. (2011). Viver sob ameaça: Preconceito, discriminação e violência homofóbica no Brasil. In G. Venturi \& V. 
Bokany (Ed.), Diversidade sexual e homofobia no Brasil (pp.73-87). São Paulo: Editora Fundação Perseu Abramo.

Dinis, F. N. (2012). Educação e diversidade sexual: Interfaces

Brasil/Canadá. Revista Educação e Cultura Contemporânea, 9(18), pp.75-96. Retrieved from

http://periodicos.estacio.br/index.php/reeduc/article/view/267/5

Foucault, M. (1999). A História da Sexualidade 1: A vontade do saber. Rio de Janeiro: Graal.

Furlani, J. (2009). Direitos Humanos, Direitos Sexuais e Pedagogia Queer:

O que essas abordagens têm a dizer à Educação Sexual? In R. D.

Junqueira (Org.), Diversidade Sexual na Educação:

Problematizações sobre a homofobia nas escolas (pp. 293-324).

Brasília: UNESCO.

Junqueira, R. D. (2009a). Homofobia nas Escolas: Um problema de todos.

In R. D. Junqueira (Org.). Diversidade Sexual na Educação:

Problematizações sobre a homofobia nas escolas (pp. 13-32).

Brasília: Ministério da Educação, Secretaria de Educação

Continuada, Alfabetização e Diversidade, UNESCO.

Junqueira, R. D. (2009b). Educação e Homofobia: O reconhecimento da

diversidade sexual para além do multiculturalismo liberal. In R. D.

Junqueira (Org.), Diversidade Sexual na Educação:

Problematizações sobre a homofobia nas escolas (pp. 367-444).

Brasília: Ministério da Educação, Secretaria de Educação

Continuada, Alfabetização e Diversidade, UNESCO.

Kamel, L., \& Pimenta, C. (2008). Diversidade sexual nas escolas: O que os profissionais de educação precisam saber. Rio de Janeiro: ABIA.

Lima, M. E. O., \& Vala, J. (2004). As novas formas de expressão do preconceito e do racismo. Estudos de Psicologia, 9(3), 401-411. doi:10.1590/S1413-294X2004000300002

Lionço, T., \& Diniz, D. (2009). Homofobia, silêncio e naturalização: Por uma narrativa da diversidade sexual. In T. Lionço \& D. Diniz (Orgs.), Homofobia \& Educação: Um desafio ao silêncio (pp. 47-72). Brasília: LetrasLivres: EdUnB.

Louro, G. L. (1997). Gênero, Sexualidade e Educação: Uma perspectiva pós-estruturalista (2a ed.). Petrópolis, RJ: Vozes. 
Louro, G. L. (2001). Teoria queer: Uma política pós-identitária para a educação. Revista Estudos Feministas, 9(2), 541-553.

doi:10.1590/S0104-026X2001000200012

Louro, G. L. (2005). O currículo e as diferenças sexuais e de gênero. In: M. V. Costa (Org.). O currículo nos limiares do contemporâneo. Rio de Janeiro: DP\&A.

Louro, G. L. (2013). Currículo, gênero e sexualidade: o "normal”, o "diferente" e o "excêntrico". In G. L. Louro; Felipe, J. \& S. V. Goellner (Orgs.), Corpo, Gênero e Sexualidade: um debate contemporâneo na educação (pp. 43-53). Petrópolis, RJ: Vozes.

Madureira, A. F. A. (2007). Gênero, Sexualidade e Diversidade Sexual na Escola: A construção de uma cultura democrática (Tese de doutorado). Brasília: UnB.

Maistro, V. I. A. (2009). Desafios para a elaboração de projetos de Educação Sexual na escola. In M. N. D. Figueiró (Org.). Educação Sexual: Em busca de mudanças (pp. 35-62). Londrina: UEL.

Meyer, D. E. E. (2013). Gênero e educação: teoria e política. In G. L. Louro, J. Felipe, \& S. V. Goellner (Orgs.), Corpo, Gênero e Sexualidade: um debate contemporâneo na educação (pp.11-29). Petrópolis, RJ: Vozes.

Nardi, H. C. (2010). Educação, heterossexismo e homofobia. In F. Pocahy (Org.), Políticas de enfrentamento ao heterossexismo: Corpo e prazer (pp. 151-167). Porto Alegre: NUANCES.

Nardi, H. C., \& Quartiero, E. (2012). Educando para a diversidade: desafiando a moral sexual e construindo estratégias de combate à discriminação no cotidiano escolar. Sexualidad, Salud y Sociedad Revista Latinoamericana, 11, 59-87. doi:10.1590/S198464872012000500004

Pereira, G. R. (2010). Decursos Educativos e Conhecimentos para uma Educação Sexual Emancipatória Intencional. Revista Linhas, 11(1), 53-67. Retrieved from http://www.periodicos.udesc.br/index.php/linhas/article/view/2016/p df_42 
Ramires, L. (2011). Homofobia na escola: o olhar de um educador. In G. Venturi \& V. Bokany, Diversidade sexual e homofobia no Brasil (pp.131-140). São Paulo: Editora Fundação Perseu Abramo.

Santos, C., \& Bruns, M. A. T. (2000). A educação sexual pede espaço: Novos horizontes para a práxis pedagógica. São Paulo: Ômega Editora.

Seffner, F. (2009). Equívocos e Armadilhas na Articulação entre Diversidade Sexual e Políticas de Inclusão Escolar. In R. D. Junqueira. (Org.), Diversidade Sexual na Educação: Problematizações sobre a homofobia nas escolas (pp. 125-140). Brasília: Ministério da Educação, Secretaria de Educação Continuada, Alfabetização e Diversidade, UNESCO.

Seffner, F. (2013). Sigam-me os bons: apuros e aflições nos enfrentamentos ao regime da heteronormatividade no espaço escolar. Educação e Pesquisa, 39(1), 145-159. doi:10.1590/S1517-97022013000100010

Silva Júnior, J. (2010). Rompendo a mordaça: Representações Sociais de Professores e Professoras do Ensino Médio sobre homossexualidade (Tese de doutorado). São Paulo: Faculdade de Educação da USP. Tosso, M. P. (2012). Formación del Profesorado en la Atención a La Diversidad Afectivo-Sexual (Tesis doctoral). Madrid: Facultad de Educación de la Universidad Complutense de Madrid. 
Elaine De Jesus Souza is student Doctorate in Education from the Federal University of Rio Grande do Sul, Brasil.

Leonor M. Cantera Espinosa is professor of Psychology at the Autonomous University of Barcelona.

Joilson Pereira da Silva is professor in the postgraduate in Social Psychology at the Federal University of Sergipe.

Claudiene Santos is Professor of Biology Department at the Federal University of Sergipe.

Contact Address: Street Ednaldo V. N. Valadares, number 60, Simão Dias, Sergipe, Brazil. CEP: 49480-000

E-mail: elaine.js.sd@hotmail.com 